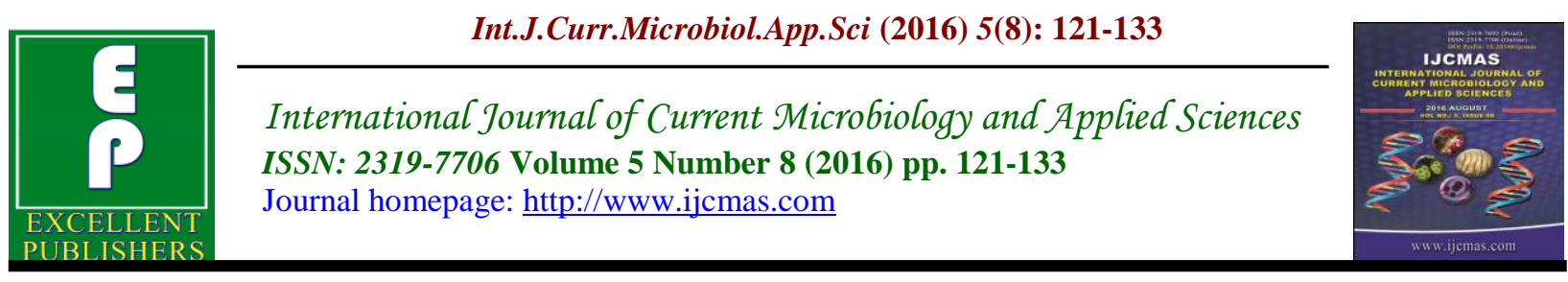

Original Research Article

http://dx.doi.org/10.20546/ijcmas.2016.508.015

\title{
Possibility of Child Food Supplement Production to Basis of Breadfruit (Artocarpus altilis)
}

\author{
Innocent Yaou Bokossa ${ }^{1}$, Estelle A. Assogba ${ }^{1}$, Célestin C.K. Tchekessi ${ }^{1}$ *, \\ Jultesse S.B. Banon ${ }^{1}$, Pivot S. Sachi ${ }^{1}$, Roseline Bleoussi ${ }^{1}$, Anayce Djogbe ${ }^{1}$, Edwige \\ Dahouenon-Ahoussi ${ }^{2}$, Auréole E.A. Bokossa ${ }^{1}$ and Justin G. Gandeho' ${ }^{1}$ \\ ${ }^{1}$ Unité de Recherche en Sécurité Sanitaire des Aliments (URSSA), Laboratoire de Microbiologie \\ et des Technologies Alimentaires (LAMITA), Université d'Abomey-Calavi, Benin \\ ${ }^{2}$ Laboratoire de Génie de Technologie Alimentaire, Ecole Polytechnique d'Abomey-Calavi \\ (EPAC), Université d'Abomey-Calavi (UAC), Benin \\ *Corresponding author
}

\section{Keywords}

Fermentation, Artocarpus altilis, malnutrition, formulation, flour, child.

\section{Article Info}

Accepted:

12 July 2016

Available Online:

10 August 2016

\section{A B S T R A C T}

Children's feeding at the age of weaning remains a major concern in all countries of the world and particularly in developing countries like Benin. In order to valorize our resources and contribute to malnutrition reduction in Benin, an alimentary supplement has been elaborated with the flour of a fermented fruit issued from a breadfruit tree. The results of physicochemical analysis revealed that this fruit had a nutritional composition of $4.2 \%$ in protein, $0.11 \%$ in crude fat, $1.8 \%$ in ash content, $712.971 \mathrm{mg} / \mathrm{g}$ in iron content, $0.099 \%$ in calcium content and $0.125 \%$ in magnesium content. The experiments of the various formulations enabled us to stop those made up of 55\% of the flour of the breadfruit, $30 \%$ of the flour of soybeans and $15 \%$ of the flour of the malted sorghum. The results of analysis showed that the retained formulation presented some contents in macro nutriments comparable to those of the norm on infantile flours. It contained $18.5 \%$ of protein and $16.3 \%$ of fat matter. The energizing value of our flour is of 456.5 $\mathrm{Kcal} / 100 \mathrm{~g}$. It was consistent with standard values of complementary weaning food recommended by FAO/OMS/UNICEF. Microbiological analysis revealed that there is no formulation of flour, which contains total coliform or thermotolerant coliforms. It's free of pathogens microorganisms such as Escherichia coli type and Salmonella.

\section{Introduction}

Malnutrition, in all its manifestations continues to affect large proportions of population of continent, despite many efforts which have been provided for the development of the agricultural sector. However, local resources rich in nutrients like the fruits of breadfruit tree are little valued.

Children's nutrition in weaning age remains a major concern in all countries of the world and particularly in developing countries 
including Benin. Indeed, from birth to the age of six months, breast milk considered as the best for newborn, is enough to satisfy and provide normal growth (Trèche, 1994). However, in the period of growth, infants and young children, especially those from 6 months to 2 years, need an alimentation rich in energy and nutrients. Poor nutrition prevents them from achieving their full potential energy (FAO, 2002). According to the research by the UNICEF (United Nations Children's Fund) in 2006 and those of the FAO (Food and Agriculture Organization of the United Nations) in 2002, malnutrition can cause when it is grave, a premature death, permanent disabilities and great fragility facing many life-threatening diseases (FAO, 2002; UNICEF, 2013). In Benin, according to Health Demographic Investigations in 2006, more than $30 \%$ of children from 0 to 2 years suffered from chronic malnutrition (INSAE, 2013). For a similar rate, children do not receive food supplements at the appropriate time or receive inappropriate alimentary supplements. To the problem of inadequate energy intake overlaps that of micronutrient deficiencies (vitamin and mineral). Those are essential for growth, development and the proper functioning of the body (FAO, 2002). In addition, the low energy density of alimentary supplement generally proposed, is recognized by the World Health Organization (WHO) as a causative factor in young children (Traore et al., 2004). Indeed, many infant complementary foods have been manufactured from rice, sorghum, soybeans, corn; so it is still possible to conceive these complementary foods from other raw materials not yet valorized locally of which the fruits of the breadfruit tree.

Still called breadfruit, Artocarpus altilis tree is a tree of the family of the Moraceae, native to Oceania, domesticate in this region by its edible fruit and now widespread in the tropics and in Benin. Bread's fruit is a great staple compares favorably with taro, plantain, cassava and sweet potato, all consumed widely in the Pacific. The fruit of breadfruit is a nutritious food of high energy with a glycemic index fiber-rich, moderate, and a good source of vitamins B1, B2 and C, potassium, magnesium and calcium, with small amounts of thiamin, riboflavin, niacin, and iron. The fruit, good source of minerals and vitamins can be consumed cooked at all stages of maturity. In Benin, this tree exists in natural state and well distributed in the center and South. In Ghana, the flour of the fruit of the breadfruit has been incorporated into nutritious foods for babies (Ragone, 2009).

Thus in the context of enhancing food, the study of the possibility of production of a child food supplement of good nutritional value, based on the fruit bread and soy, two locally available food resources, represents an alternative in the fight against malnutrition. However, malted sorghum is used as a source of amylase to improve the nutrition of infants and the functional properties of the traditional boiled.

It's for contributing to children's food security at weaning age through breadfruit valorization in Benin that we chose to conduct this research entitled: Possibility of production of infant complementary foods to basis of breadfruit (Artocarpus altilis).

The overall objective of this study is to valorize the fruit of the breadfruit tree in sight of bring into focus a child food supplement of good quality for children at the age of weaning.

\section{Materials and Methods}

\section{Collection of raw material}

The plant material constituted of fruit of the breadfruit (Artocarpus altilis), sorghum 
(Sorghum bicolor) and soybean (Glycine max) bought at the market of AbomeyCalavi in Benin.

The water from the National of Water Company of Benin (SONEB), bowls, trays, pans, slicers, the oven HERAEUS, mark electric mill No.1A AMUDA GRINDING MILL and bleach were also used.

\section{Methods of production and analysis}

The method used is based on experimentation, microbiological, physicochemical, sensory and statistical analysis.

\section{Phase of experiments}

The work of experiments were consisted to product the flour fruit breadfruit, the malted sorghum flour, soybean flour (Figure 1, 2, 3) and the formulation of infant complementary foods (Table 1).

\section{Production of flour breadfruit}

Technological diagram in figure 1 showed the production of the flour of the breadfruit.

\section{Production of malted sorghum flour}

Malted sorghum flour has been prepared in accordance with the methods described by (Traore et al., 2004) and Kayode (2006) following five main steps below (Figure 2):

Soaking: It is to soak the previously sorted seeds in water for $16 \mathrm{~h}$.

Germination: Sorghum seeds are removed from the soaking water and are spread in the hotbed for $56 \mathrm{~h}$.

Drying: Sprouted seeds are dried in the Sun for $10 \mathrm{~h}$.
Degerming: The obtained dried seeds are free of root and stem.

Grind: Degermed seeds are crushed to the mill and we get flour malted that on Thames to rid the flour of debris.

\section{Preparation of soybean flour}

Soybean flour has been developed by the method proposed by Schemp (1994). Employed technology operations are described in the following way:

Sorting: separation operation. Here the soy bean sorted to remove the rotten and damaged seeds and foreign material, so that it only remains good seeds.

Weighing: sorted seeds were weighed in order to know the amount of material that goes into production

Cooking: soya beans have been pre-cooked in water (PV: $1 / 6)$ at $100{ }^{\circ} \mathrm{C}$ for $30 \mathrm{~min}$ in a saucepan. According to Egounlety (2002), this firing to destroy $90 \%$ of the inhibitory trypsin contained in soybeans.

Drip: soybeans are drained using a strainer to separate them from the cooking water.

Drying: soybean seeds precooked and drained are spread on the HERAEUS oven trays to be subjected to drying.

Grind: obtained after drying dry soybean seeds are ground using the electric mark mill $\mathrm{N}^{\circ} 1$ A AMUDA GRINDING MILL. electric mill

Sieving: soy flour after milling is subject to sifting through a sieve that holds the fibers and seeds not entirely ground soy and it gets close to use soy flour. Figure 3 indicated the technological diagram of the production of flour of malted sorghum. 


\section{Formulation of infant complementary food}

Infant complementary food has been formulated using pre-prepared meals. Indeed the formulation of the food supplement is based on a theoretical calculation. Do this by referring to the work of Traore et al. (2004) reported that irrespective of the raw materials used to develop a child meal, the rate of incorporation of malted sorghum flour can be between 10 to $15 \%$. To obtain a slurry of acceptable energy density, we fixed the rate of incorporation of malted sorghum flour at $15 \%$. Other raw materials, namely the fermented flour fruit breadfruit and soy flour are used in various proportions (Table 1).

\section{Assessment of microbiological quality}

Microbiological analysis consisted in counting the total mesophilic flora (NF ISO 4833, 2003) on PCA (Oxoid CM 0325), yeasts and molds (NF ISO 21527-2, 2008) on Sabouraud Dextrose Agar (Oxoid CM 0041) at chorampphénicol $(0.05 \mathrm{~g} / \mathrm{l})$, total coliforms (NF ISO 4832 (V 08-015), 2006) and thermotolerant coliforms (NF ISO 4832 (V08-060), 2009) on VRBA-Oxoid CM 0107 (Violet Red Bile Agar), and Salmonella (ISO 6579, 2002) on SS Agar. Microbiological analyzes were performed in triplicate on each sample.

\section{Evaluation of the physico-chemical quality}

Physico-chemical analyzes were conducted to know the $\mathrm{pH}$, titratable acidity, moisture content, ash, crude protein, crude fat, carbohydrate, calcium, magnesium and iron, on the sample. Thus, the $\mathrm{pH}$ and titratable acidity were determined by the modified method of Nout et al., (1989). The moisture content and dry matter were determined by the method (AACC, 1984) from $5 \mathrm{~g}$ of product by drying and by differential weighing. The ash content was determined from the dry matter by calcination at $550{ }^{\circ} \mathrm{C}$ for $12 \mathrm{~h}$. The crude protein content $(\mathrm{N} \mathrm{x}$ 6.25 ) was determined by the micro Kjeldahl method. The crude fat was determined by the standard method "Soxhlet" using a GRAS DET-N equipment which operates by electrical heating and that is a grease extractor solvent. The minerals, Calcium, magnesium and iron were determined by Atomic Absorption Spectrophotometer (AAS) as per the standard method. Total available carbohydrate was calculated as $100 \%$ minus the sum of moisture, protein, fat and ash content obtained as described above. All determinations were carried out in triplicates.

\section{Determination of the meal energy}

The energy value of a food compound is the sum of the products of each major food (carbohydrates, proteins, lipids) and its thermal coefficient of Atwater correspondent (Zannou Tchoko et al., 2011). Thus, the energy value (EV) per 100g of the sample was then obtained by the formula: $\mathrm{VE}(\mathrm{Kcal})=$ Protein $(\%) \times 4+$ carbohydrates $(\%) \times 4+$ lipids $(\%) \times 9$.

\section{Sensory evaluation}

Sensory analysis was performed according to the methods of comparison described by Larmond (1977) quoted by Bokossa et al. (2011). A panel of tasters consisting of 33 people, consumers was established. They were randomly selected and trained for the purpose. The test objective is to identify the differences between the various types of infant flour and know the consumer preference. Tested parameters are: color, taste, acidity, aroma (smell), texture (consistency) and overall acceptability on a 
scale of 1 to 9 with $1=$ extremely unpleasant, $5=$ identical to the reference sample is a brand of infant flour "VIE VITAL VITA" sold in Benin and $9=$ extremely pleasant. Each treatment was evaluated three times by each panelist.

\section{Statistical analyzes of data}

The Excel software was used to perform the calculations. Analysis results were processed using Minitab 14.0 software that permitted to make analysis of variance (ANOVA) and Tukey's test for comparison of means. The significance level of $5 \%$ is selected $(\mathrm{p}<0.05)$.

\section{Results and Discussion}

\section{Yield of production}

The yields of production of different flours made were shown in Table 2

\section{Physicochemical characteristics of breadfruit (Artocarpus Altilis)}

The results of the physicochemical parameters of Artocarpus altis are indicated in Table 3.

\section{Physicochemical characteristics of flours produced}

Table 4 showed the physicochemical characteristics of different manufactured flours.

Physicochemical characteristics and caloric energy values of formulated flours F60, F55, and F50

Pysico-chemical composition and caloric energy values assessment of different infant coplementary foods to bring into focus were shown in table 5.

\section{Microbiological characteristics of flours}

The results of the microbiological analysis are shown in Table 6.

\section{Production test of porridge}

Porridge preparation tests reveal that infant based flour Artocarpus altis served to acceptable consistency of porridge prepared with $250 \mathrm{~g}$ for $500 \mathrm{~mL}$ of water. By cons, commercial flour was used to acceptable consistency of porridge prepared with dry matter $150 \mathrm{~g}$ for $500 \mathrm{~mL}$ of water.

\section{Sensory profiles characteristic of porridge}

Sensory profiles results of baby complementary foods produced were indicated in figures 4, 5, 6 and 7 .

Breadfruit dry matter content is $31.496 \%$. This value was lightly inferior to $33 \%$ obtained by Jagtap et Bapat (2010). This difference in dry matter can be related to the fact that the studied fruits are produced in different agro-ecological environments or are harvested in different seasons. Proteins contents of breadfruit are higher than those obtained (1.90\%) by Jagtap et Bapat (2010). This difference would be tied in the state fruit ripening for harvest, and the ash content is $1.8 \%$.

Iron contents of breadfruit are higher than those obtained $(500 \mathrm{mg} / 100 \mathrm{~g})$ by Jagtap et Bapat (2010). By cons calcium content of breadfruit are lower than the value $(20 \mathrm{mg} / 100 \mathrm{~g})$ obtained by Jagtap et Bapat (2010).

Dry matter contents and ash content of breadfruit flour obtained in our study (94. $5 \%, 0.75 \%$ respectively) were lightly inferior to $(95.7 \%, 3.4 \%$ respectively) obtained by Hedji (2010). This difference 
might depend on the fermentation process. The value of the protein content (4.28\%) recorded for our flour is comparable to that published by Hedji (2010).

The nutritional composition of malted sorghum flour revealed that it contained protein levels $(10.5 \%)$ and ash $(1.8 \%)$ higher than the fermented breadfruit flour respectively. This shows that the malted sorghum flour, although it increases the energy density of weaning porridges, it could serve to complement the breadfruit flour, low in proteins and minerals to the complementary weaning food formulation. The ANOVA performed on the physicochemical characteristics of malted sorghum flour, breadfruit revealed that there is a significant difference between produced flours in protein contents, $\mathrm{pH}$, ash content, titratable acidity, Iron, Calcium and Magnesium except dry matter at the 5\% because the probabilities are all less than $0.05(\mathrm{P}<0.05)$ except that of matter dried.

Table.1 Formulation of infant complementary food

\begin{tabular}{lccc}
\hline Designation & Artocarpus altilis flour (\%) & Soybean flour (\%) & Malted sorghum flour (\%) \\
\hline F60 & 60 & 25 & 15 \\
F55 & 55 & 30 & 15 \\
F50 & 50 & 35 & 15 \\
\hline
\end{tabular}

Table.2 Yield of different flours produced

\begin{tabular}{ll}
\hline Flours & Yield $(\%)$ \\
\hline Breadfruit & $13.56 \pm 0.32$ \\
Soybean flour & $54.94 \pm 0.015$ \\
Sorghum flour & $49.08 \pm 0.05$ \\
\hline
\end{tabular}

Table.3 Physicochemical characteristics of Artocarpus altilis

\begin{tabular}{lllllllll}
\hline $\begin{array}{l}\text { Raw } \\
\text { materials }\end{array}$ & $\begin{array}{l}\text { Dry matter } \\
(\%)\end{array}$ & $\begin{array}{l}\text { Proteins } \\
(\%)\end{array}$ & $\begin{array}{l}\text { Ash } \\
(\%)\end{array}$ & $\mathrm{pH}$ & $\begin{array}{l}\text { Titratable } \\
\text { acidity }(\%)\end{array}$ & $\begin{array}{l}\text { Calcium } \\
(\mathrm{mg} / 100 \mathrm{~g})\end{array}$ & $\begin{array}{l}\text { Iron } \\
(\mathrm{mg} / 100 \mathrm{~g})\end{array}$ & $\begin{array}{l}\text { Magnesium } \\
(\mathrm{mg} / 100 \mathrm{~g})\end{array}$ \\
\hline Fermented & $31.5 \pm 0.02$ & 4.3 & 1.8 & 5.15 & 6.8 & 9.9 & 553 & 12.5 \\
breadfruit & & \pm 0.05 & \pm 0.07 & \pm 0.24 & \pm 0.08 & \pm 0.00 & \pm 0.001 & \pm 0.00 \\
\hline
\end{tabular}

Data represents in table is mean of three replications. \pm Standard deviation.

Table.4 Physicochemical characteristics of Artocarpus altilis flour, soybean flour and malted sorghum flour.

\begin{tabular}{llll}
\hline Evaluted parameters & Artocarpus altilis flour & Soybean flour & Malted sorghum flour \\
\hline $\mathrm{pH}$ & $4.16 \pm 0.04^{\mathrm{a}}$ & $6.315 \pm 0.085^{\mathrm{b}}$ & $5.155 \pm 0.005^{\mathrm{c}}$ \\
Proteins (\%) & $4.35 \pm 0.15^{\mathrm{a}}$ & $44.215 \pm 0.115^{\mathrm{b}}$ & $10.55 \pm 0.05^{\mathrm{c}}$ \\
Dry matter (\%) & $94.501 \pm 0.499^{\mathrm{a}}$ & $95.805 \pm 0.205^{\mathrm{a}}$ & $94.465 \pm 0.315^{\mathrm{a}}$ \\
Ash (\%) & $0.75 \pm 0.05^{\mathrm{a}}$ & $4.165 \pm 0.015^{\mathrm{b}}$ & $1.4 \pm 0.1^{\mathrm{c}}$ \\
Titratable acidity (\%) & $9.29 \pm 0.09^{\mathrm{a}}$ & $15.765 \pm 0.235^{\mathrm{b}}$ & $11.25 \pm 0.05^{\mathrm{c}}$ \\
Iron (mg/100g) & $712.92 \pm 0.05^{\mathrm{a}}$ & $*$ & $154.67 \pm 0.34^{\mathrm{c}}$ \\
Calcium (mg/100g) & $5.5 \pm 0.006^{\mathrm{a}}$ & $*$ & $3.1 \pm 0.001^{\mathrm{c}}$ \\
Magnesium (mg/100g) & $4.8 \pm 0.001^{\mathrm{a}}$ & $*$ & $15.5 \pm 0.001^{\mathrm{c}}$ \\
\hline
\end{tabular}

Mean values with the same letter in the same column are not significantly different at the 5\% level. Data represents in table is mean of three replications. \pm Standard deviation. (*): traces 
Table.5 Physico-chemical characteristics and caloric energy values of formulated flours F60, F55, and F50

\begin{tabular}{llllllllll}
\hline $\begin{array}{l}\text { Flours } \\
\text { samples }\end{array}$ & pH & $\begin{array}{l}\text { Titratable } \\
\text { acidity } \\
(\%)\end{array}$ & $\begin{array}{l}\text { Dry } \\
(\%)\end{array}$ & matter & Ash $(\%)$ & $\begin{array}{l}\text { Carbohydrate } \\
(\%)\end{array}$ & Fat $(\%)$ & $\begin{array}{l}\text { Proteins } \\
(\%)\end{array}$ & $\begin{array}{l}\text { Energy value } \\
(\mathbf{\% c a l} / 100 g)\end{array}$ \\
\hline F50 & $6.15 \pm 0.05^{\mathrm{a}}$ & $1.65 \pm 0.15^{\mathrm{a}}$ & $96.7 \pm 0.06^{\mathrm{a}}$ & $2.35 \pm 0.05^{\mathrm{a}}$ & $48.5 \pm 0.31^{\mathrm{a}}$ & $21.4 \pm 0.17^{\mathrm{a}}$ & $24.5 \pm 0.08^{\mathrm{a}}$ & $484.6 \pm 0.03^{\mathrm{a}}$ \\
$\mathbf{F 5 5}$ & $5.48 \pm 0.03^{\mathrm{b}}$ & $1.45 \pm 0.05^{\mathrm{a}}$ & $96.5 \pm 0.05^{\mathrm{a}}$ & $2.75 \pm 0.05^{\mathrm{b}}$ & $58.95 \pm 0.15^{\mathrm{b}}$ & $16.3 \pm 0.375^{\mathrm{b}}$ & $18.5 \pm 0.5^{\mathrm{b}}$ & $456.5 \pm 0.015^{\mathrm{b}}$ \\
$\mathbf{F 6 0}$ & $5.2 \pm 0.02^{\mathrm{c}}$ & $1.77 \pm 0.03^{\mathrm{a}}$ & $96.2 \pm 0.24^{\mathrm{a}}$ & $2.95 \pm 0.05^{\mathrm{c}}$ & $69.15 \pm 0.05^{\mathrm{c}}$ & $12.2 \pm 0.09^{\mathrm{c}}$ & $11.9 \pm 0.06^{\mathrm{c}}$ & $434 \pm 0.01^{\mathrm{c}}$ \\
\hline
\end{tabular}

Mean values with the same letter in the same column are not significantly different at the 5\% level. Data represents in table is mean of three replications. \pm Standard deviation.

Table.6 Microbiological characteristics of flours

\begin{tabular}{llllll}
\hline \multicolumn{6}{l}{ Wanted microorganisms $\left(\log _{10} \mathrm{CFU} / \mathrm{g}\right)$} \\
\hline Flours & $\begin{array}{l}\text { Total } \\
\text { mesophilic flora }\end{array}$ & Yeasts and molds & Total coliforms & $\begin{array}{l}\text { Thermotolerant } \\
\text { coliforms }\end{array}$ & Salmonella \\
& $8.12 \pm 1.1^{\mathrm{a}}$ & $8.07 \pm 1.64^{\mathrm{a}}$ & $\mathrm{Abs}^{\mathrm{a}}$ & $\mathrm{Abs}^{\mathrm{a}}$ & $\mathrm{Abs} / 25 \mathrm{~g}^{\mathrm{a}}$ \\
\hline F50 & $2.5 \pm 0.2^{\mathrm{a}}$ & $2.2 \pm 0.0^{\mathrm{a}}$ & $\mathrm{Abs}^{\mathrm{a}}$ & $\mathrm{Abs}^{\mathrm{a}}$ & $\mathrm{Abs} / 25 \mathrm{~g}^{\mathrm{a}}$ \\
F55 & $8.17 \pm 0.0^{\mathrm{a}}$ & $6.17 \pm 1.4^{\mathrm{a}}$ & $\mathrm{Abs}^{\mathrm{a}}$ & $\mathrm{Abs}^{\mathrm{a}}$ & $\mathrm{Abs} / 25 \mathrm{~g}^{\mathrm{a}}$ \\
\hline F60 & $<10^{3} / \mathrm{g}$ & $<10 / \mathrm{g}$ & $<1 / \mathrm{g}$ & $\mathrm{Abs} / 25 \mathrm{~g}$ \\
\hline Norms & $<10^{5} / \mathrm{g}$ & &
\end{tabular}

Mean values with the same letter in the same column are not significantly different at the 5\% level. Data represents in table is mean of three replications. \pm Standard deviation. Abs: Absent.

Fig.4 Porridge taste appreciation

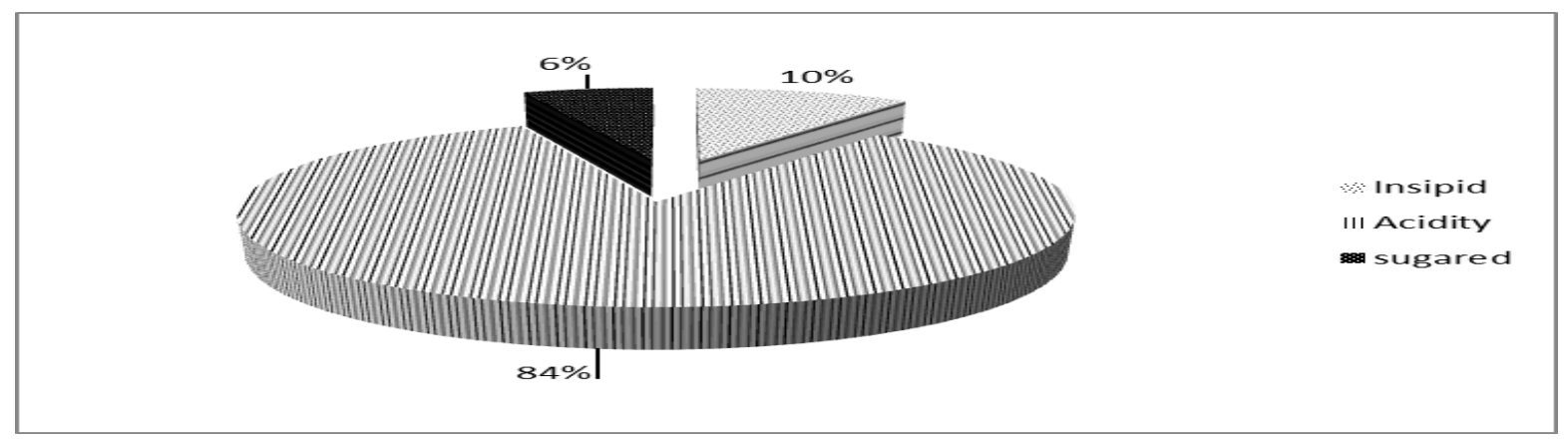

Fig.5 Porridge color assessment

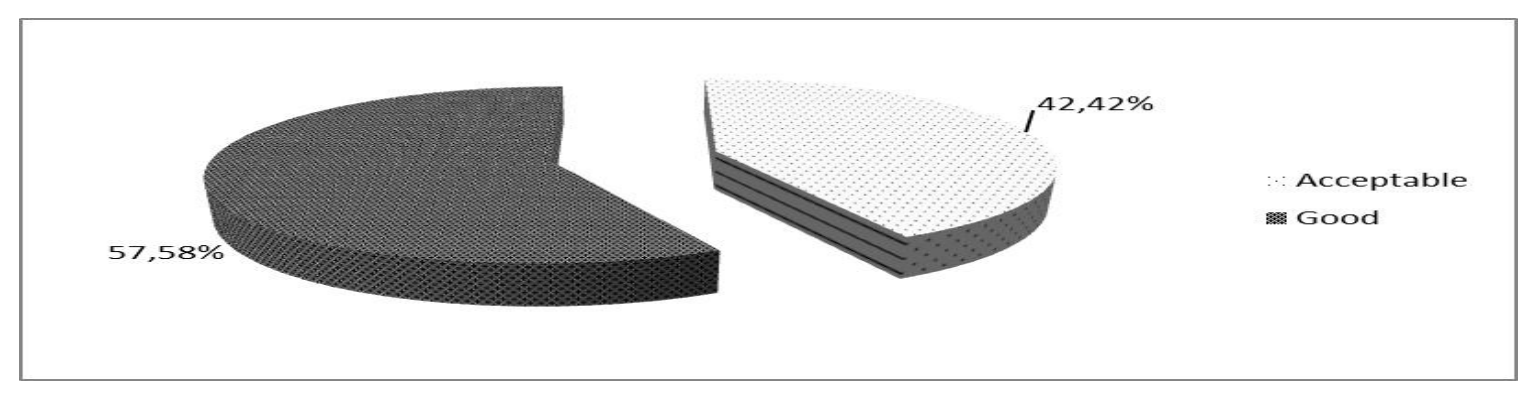




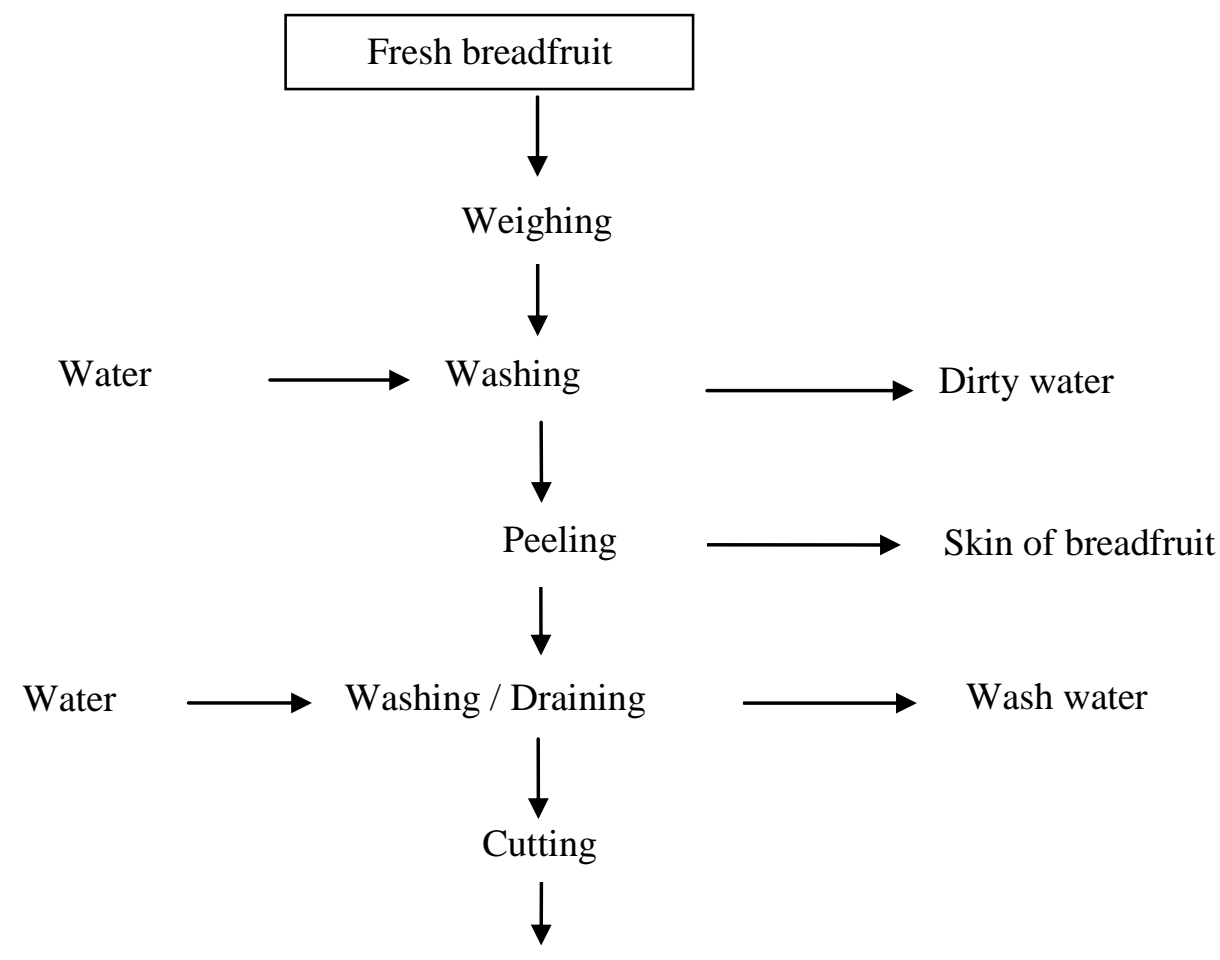

Fermentation $\left(25^{\circ} \mathrm{C} ; 72 \mathrm{~h}\right)$

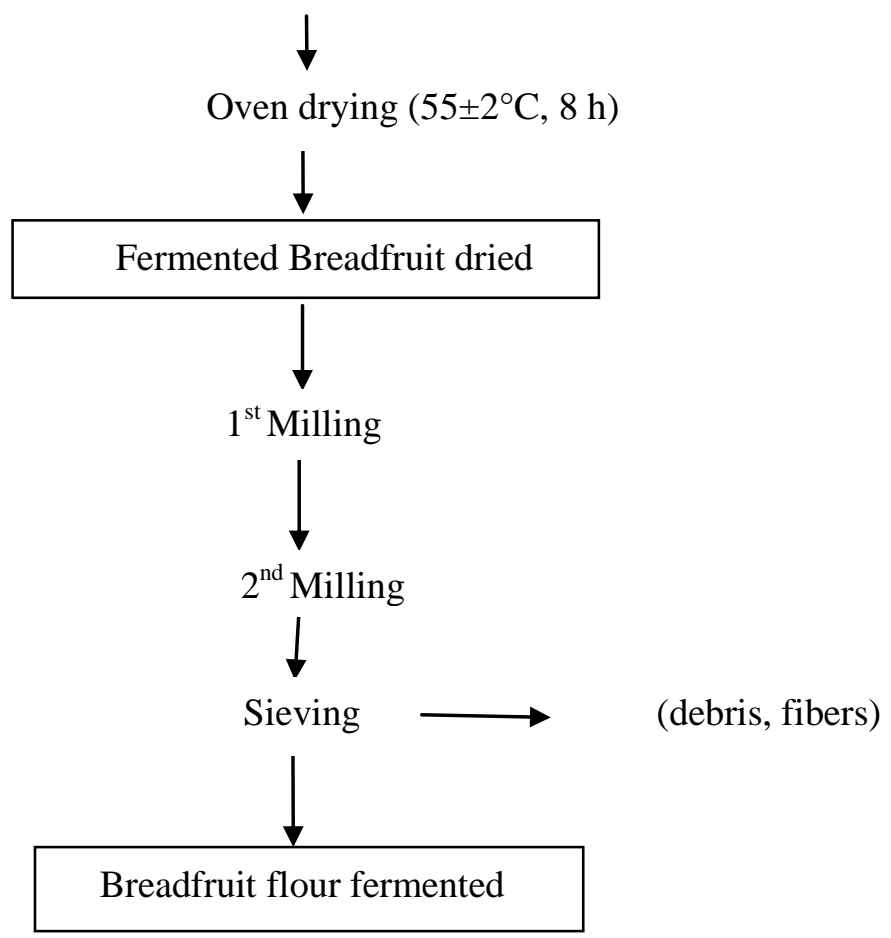

Figure 1. Technological diagram of production of breadfruit flour fermented 


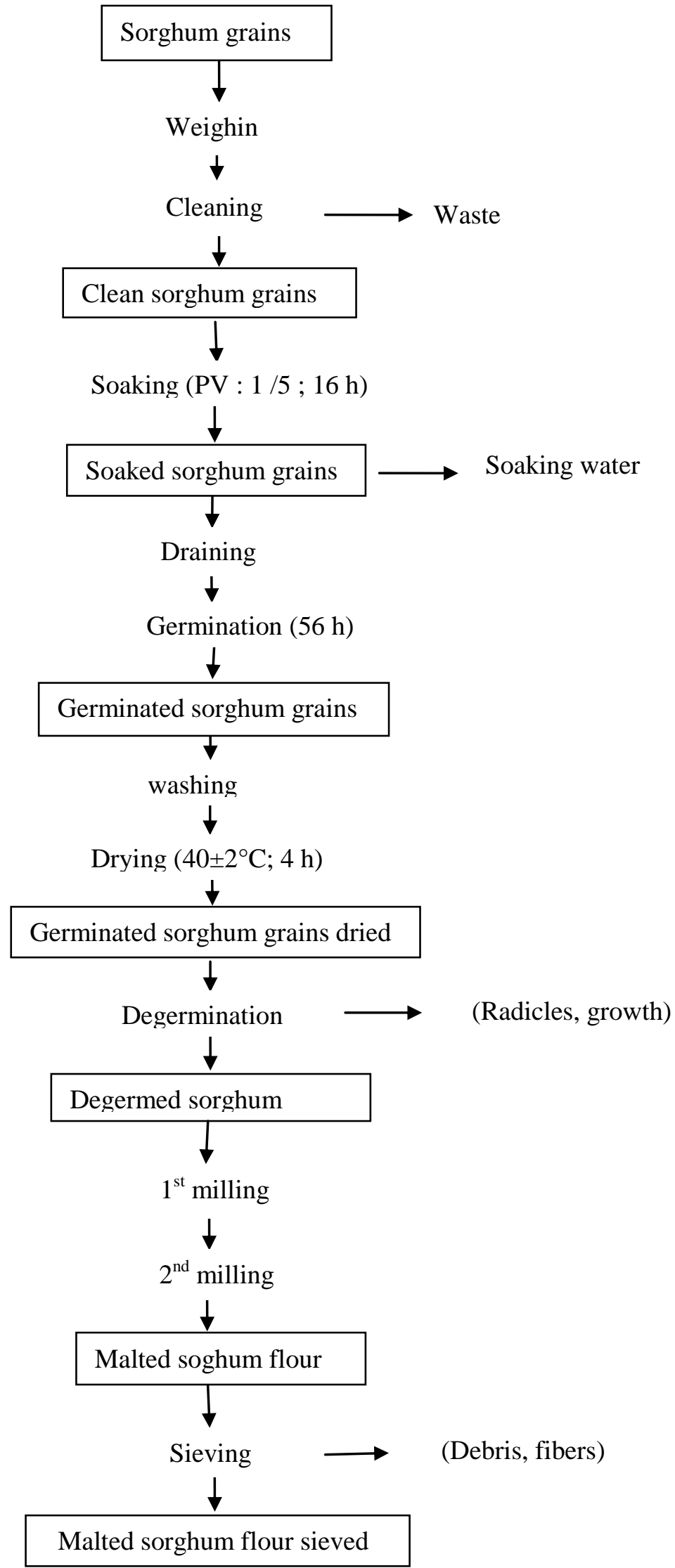

Figure 2. Technological diagram of production of malted sorghum flour 


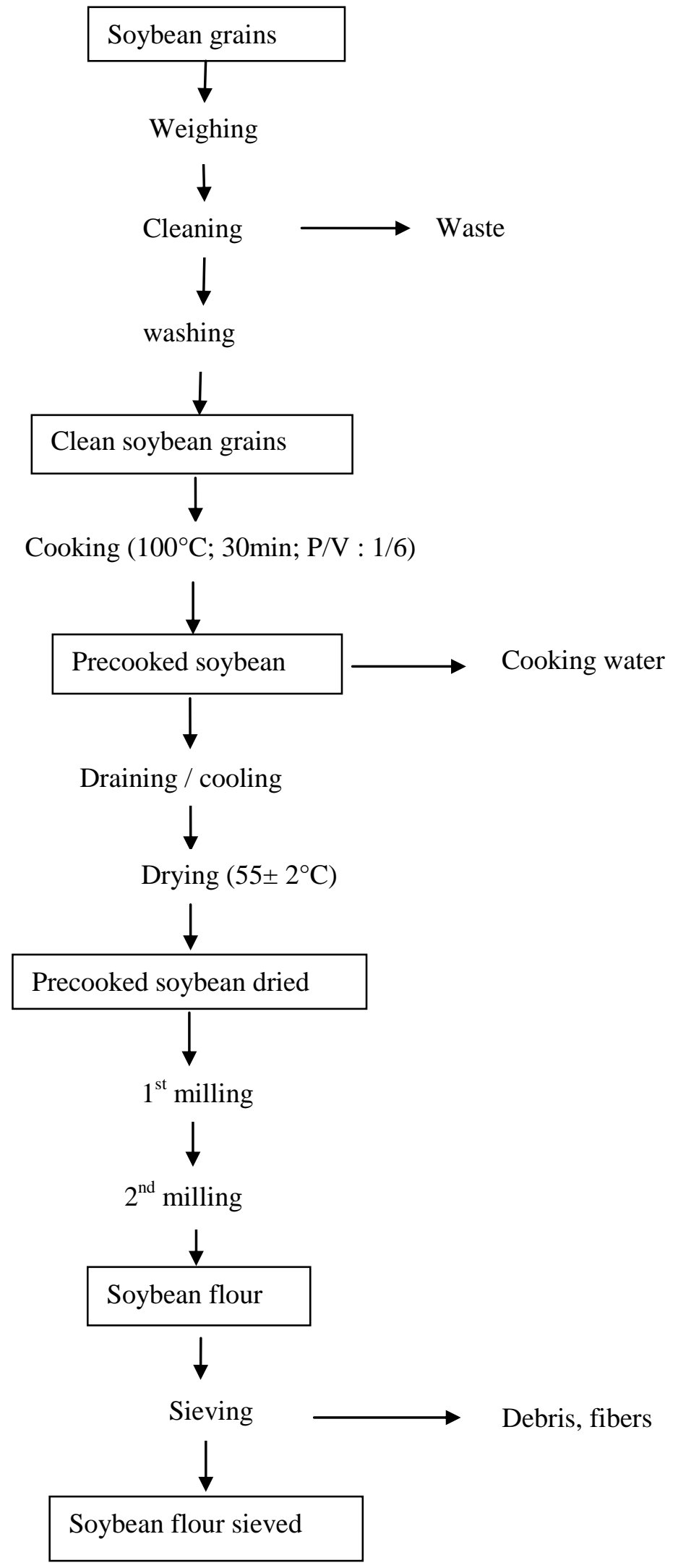

Figure 3. Technological diagram of soybean flour 
Fig.6 Porridge consistency assessment

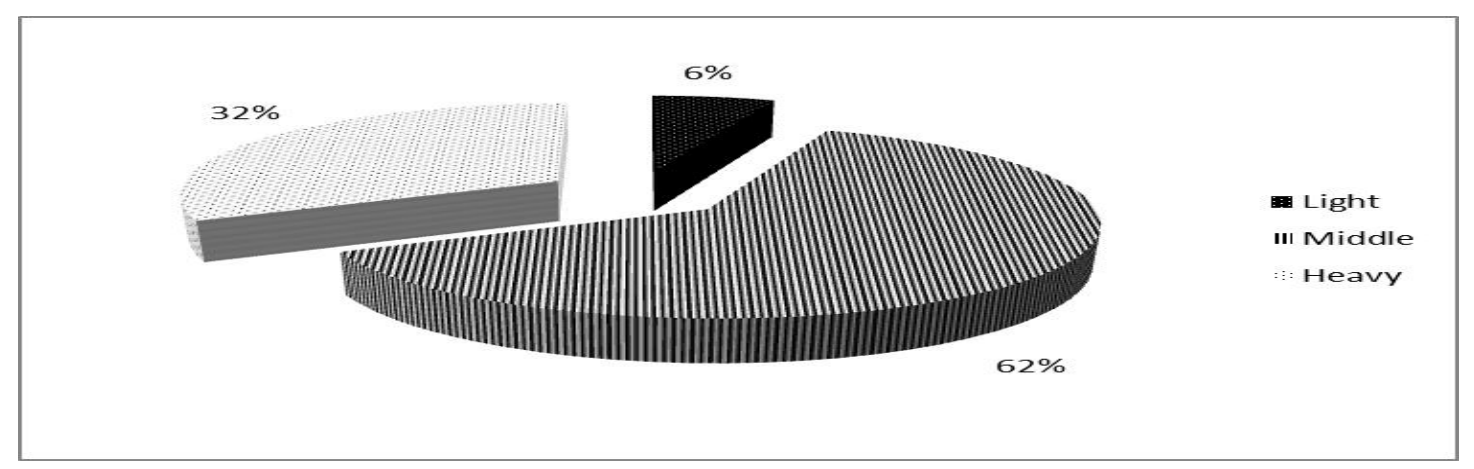

Fig.7 Overall acceptability of porridge

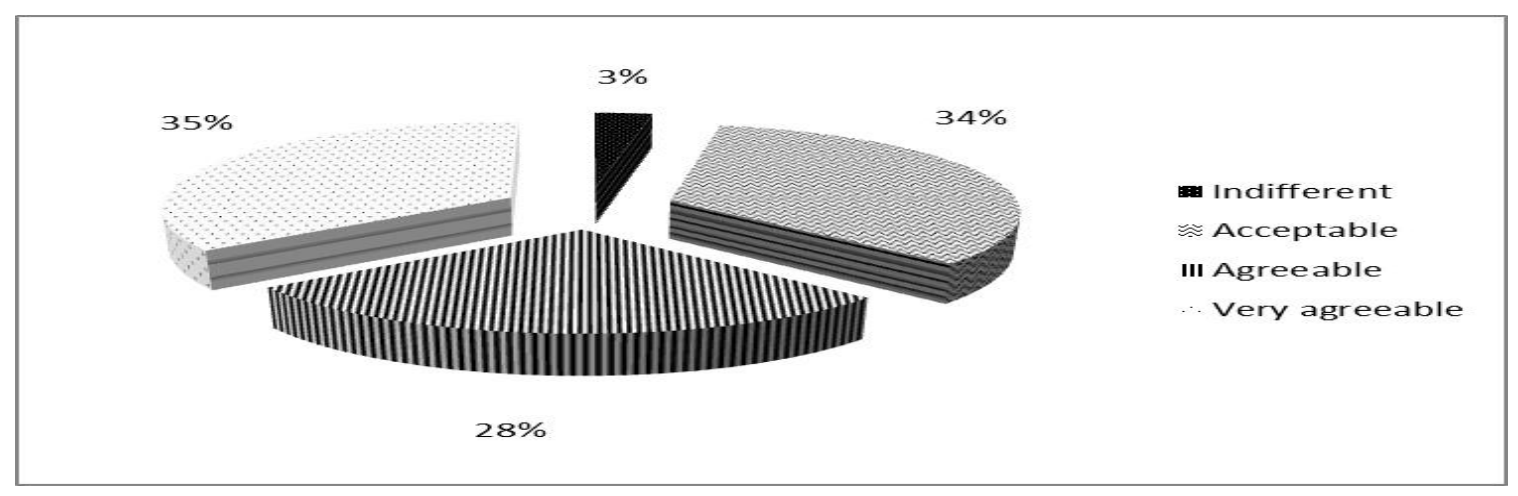

Variance analysis (ANAOVA) performed on the physicochemical characteristics of flours F50, F55, and F60 indicated that there is a significant difference between the flours from the point view of protein content, fat, ash content, and $\mathrm{pH}$ at $5 \%(\mathrm{p}<0.05)$. By cons there is no significant difference between the flours from the point of view of the dry matter content and titratable acidity at 5\% level ( $p>0.05)$.

In the formulations F50, F55, and F60, we see that most soy intake increases in formulating their more protein, fat and ashes even increase. These observations justify much the soybean role in improving the contents proteins and fat. Note also that when the proportion of breadfruit flour increases in infant flour, carbohydrate contents are improved. Analysis of nutritional composition of its formulations show that the F60 flour has a protein content
(11.9\%) inferior at $16.9 \%$ recommended by the standards FAO/WHO/UNICEF (2009) for infants from six to two years. Similarly, F50 flours, and F55 are respectively 24.5\% and $18.5 \%$ of protein content and greater than $16.9 \%$. However, the F50 formulation contains $5.71 \%$ (protein) per $100 \mathrm{kcal}$. This rate exceeds the upper limit $5.5 \%$ per 100 kcal. Similarly, the F55 formulation contains $3.86 \%$ of protein per $100 \mathrm{kcal}$, which respects the standard. By cons, all porridges have a lipid contents which are consistent with standard. Hence the F55 formulation is used, to serve as a good complementary food for children from six months to two years.

The carbohydrate content of the F55 flour $(58.95 \%)$ is lower than those $(64.15 \%)$ of reference sample, however, the contents of proteins and fat found in the F55 flour are consistent with standards values of proteins 
$(16.9 \%)$ and fat $(6-10 \%)$ set by the FAO/WHO/UNICEF (2009). The ash contents of F55 flour (2.7\%) higher than those $(2.2 \%)$ contained in the flour reference, are consistent with norms. The energy content of the F55 flour (458.74 $\mathrm{kcal} / 100 \mathrm{~g}$ ) is higher than the energy value of reference flour and remained consistent with norms.

The appreciation test of porridge by mothers consists of a sensory appreciation of this porridge which was globally accepted. Indeed, mothers were chosen as taster because they play an important role in the diet of their children.

The breadfruit is a fruit rich in nutrient; the flour obtained by application of good production practices helped to formulate a good complementary food. The baby's formulated F55 flour has a nutritional quality and organoleptic quality appreciable. Its energy density is improved by the incorporation of $15 \%$ of malted sorghum flour. This flour has a protein content, fat, energy consistent with the recommendations of the $\mathrm{FAO} / \mathrm{WHO} / \mathrm{UNICEF}$ committee for the nutritional composition.

\section{Acknowledgements}

The authors thank very sincerely the SSA NGO's : Health and Food Safety (HFS), for the practical arrangements that had been taking in the realization of the experiments on his site.

\section{References}

AACC. 1984. Approved Methods of the American Association of Cereals Chemists. $8^{\text {th }}$ ed. St Paul. MN. USA. 53p.

Bokossa Yaou, I., C.K.C., Tchekessi, P., Dossou-Yovo, M., Egounlety, et Dossa, R.M., 2011. Substitution partielle du lait en poudre par le lait de soja pour la production du yaourt. Bulletin de la Recherche Agronomique du Bénin. Vol. 69, pp. 48-55.

Dubois, M., K.A., Gilles, J.K., Hamilton, T.J., Schotch, P.A., Rebers, and Smith F., 1956. Colorimetric method for determination of sugar and related substances. Anal. Chem., Vol. 28, No. 3, pp. 350-356.

Egounlety, M. 2002. Production of legumefortified weaning foods. Food Res. Int., 35, pp 233-237.

FAO. 2012. Traitement et préparation à domicile des aliments de sevrage, htpp: //www.fao.org./docrept/003/ T0554E15.htm. Consulté le 11/11/2011.

FAO/WHO/UNICEF. 2009. Programme mixte FAO/OMS sur les normes alimentaires. Commission du Codex Alimentarius, $32^{\text {ème }}$ session Rome (Italie), 29 juin-4 juillet 2009. Rapport de la $30^{\text {ème }}$ session du comité du codex sur la nutrition et les aliments diététiques ou de régime. Le Cap (Afrique du Sud) 3-7 Novembre 2008. pp 1-223.

Hedji, C.C. 2010. Production et utilisation de la farine des fruits de l'arbre à pain (Artocarpus altilis) en boulangeriepâtisserie. Mémoire de Master, Faculté des Sciences et Techniques, Université d'Abomey-Calavi, Bénin, 51p.

INSAE (Institut National de la Statistique et de l'Analyse Economique). 2013. Résultats du quatrième Recensement Général de la Population et de l'Habitation (RGPH4), République de Bénin, 8p.

Jagtap, U.B., Bapat, V.A. 2010. Artocarpus: A review of its traditional uses, phytochemistry and pharmacology. $J$. Ethnopharmacol., 12(9): 143-144.

Kayode, P. 2006. Diversity, user's perception and food processing of Sorghum: implication for dietary iron and zinc supply. Thèse de doctorat à 
1'Université de Wageningen. Pays-Bas. pp 11-20 and pp113-128.

NF ISO 21527-2, 2008. Microbiologie des aliments, Méthode horizontale pour le dénombrement des levures et moisissures. Partie 2 : technique par comptage des colonies dans les produits à activité d'eau inférieure ou égale à $0,95.9 \mathrm{p}$.

NF ISO 4832 (V 08-015), 2006. Microbiologie des aliments, Méthode horizontale pour le dénombrement des coliformes. Méthode par comptage des colonies obtenues à $37^{\circ} \mathrm{C} .6 \mathrm{p}$.

NF ISO 4833, 2003. Microbiologie des aliments, Méthode horizontale pour le dénombrement des micro-organismes. Technique de comptage des colonies à $30^{\circ} \mathrm{C}$ sur PCA. $19 \mathrm{p}$.

NF ISO 6579, 2002. Microbiology of food and animal feeding stuffs, Horizontal method for the detection of Salmonella spp. Fourth edition. 34p.

NF ISO4832 (V08-060), 2009. Microbiologie des aliments, Dénombrement des coliformes thermotolérants par comptage des colonies obtenues à $44^{\circ} \mathrm{C}$. Biokar diagnostics Violet Red Bile Agar (VRBA). 4p.

Nout, M.J.R., F.M., Rombouts, and Havelear, A. 1989. Effect of accelerated natural lactic fermentation of infant food ingredients on some pathogenic microorganisms. Int. J. Food Microbiol., 8(4): 351-361.
Ragone, D. 2009. Farm and forestry production and marketing Profile for breadfruit (Artocarpus altilis), 137p.

Schemp, R. 1994. Comment utiliser les graines de soja à la cuisine. Ed SECAAR (Service Chrétien d'Appui à l'Animation Rurale), 15p.

Traoré, C., C., Mouquet, C., Icard-Vreniere, A., Traoré and Trèche, S. 2004. Change in nutriment composition, phytate and cyanide content and $\alpha$-amylase activity during cereal malting in small production unit in Ouagadougou (Burkina-Faso). Food Chem., 88, pp 105-114.

Trèche, S. 1994. Technique pour augmenter la densité énergétique des bouillies, In : L'alimentation de complément du jeune enfant (Trèche $S$, de Benoist $B$, Benbouzid D \& Delpeuch F, éds.). Actes d'un atelier OMS/ORSTOM inter-pays, Université Senghor, Alexandrie (Egypte), pp 123-145.

UNICEF (Fonds des Nations Unies pour l'Enfance), 2013. Améliorer la nutrition de l'enfant: un objectif impératif et réalisable pour le progrès mondial. Publication des Nations Unies. Etats Unis. $132 \mathrm{p}$.

Zannou Tchoko, V.J., K.G.M., Bouaffou, K.G., Kouame, et Konan, B.A. 2011. Etude de la valeur nutritive de farines infantiles à base de manioc et de soja pour enfant en âge de sevrage. Bulletin de la Société Royale des Sciences de Liège, Vol. 80, pp. 748-758.

\section{How to cite this article:}

Innocent Yaou Bokossa, Estelle A. Assogba, Célestin C.K. Tchekessi, Jultesse S.B. Banon, Pivot S. Sachi, Roseline Bleoussi, Anayce Djogbe, Edwige Dahouenon-Ahoussi, Auréole E.A. Bokossa and Justin G. Gandeho. 2016. Possibility of Child Food Supplement Production to Basis of Breadfruit (Artocarpus altilis). Int.J.Curr.Microbiol.App.Sci. 5(8): 121-133. doi: http://dx.doi.org/10.20546/ijcmas.2016.508.015 